\title{
A Chinese case of fragile X-associated tremor/ataxia syndrome (FXTAS) with orthostatic tremor:case report and literature review on tremor in FXTAS
}

\author{
Cuiping Zhao ${ }^{\text {** }}$, Yiming Liu', Yihua Wang ${ }^{2}$, Hongyan Li ${ }^{1}$ Bin Zhang ${ }^{1}$, Yaoxian Yue ${ }^{1}$ and Jianyuan Zhang ${ }^{1}$
}

\begin{abstract}
Background: Fragile X-associated tremor/ataxia syndrome (FXTAS) is a late onset, $X$-linked genetic, neurodegenerative disorder caused by a "premutation (PM)" in the fragile X mental retardation 1 (FMR1) gene. Here we report a case of FXTAS from mainland of China who presented with rare orthostatic tremor. A review of tremor of FXTAS in the literature is also included.

Case presentation: A 67-year-old right-handed farmer started with tremor of both legs 8 years ago which was present while standing but absent when sitting or lying and progressed with unsteady gait one and a half years ago. The brain MRI showed high intensity signal in the bilateral middle cerebellar peduncles (MCP) in T2-weighted and fluid-attenuated inversion recovery (FLAIR) images and gene test for premutation for FMR1 was positive with 101 CGG repeats. The patient met the the diagnosis of definite FXTAS. Clonazepam and topiramate were administered to control tremor. We reviewed the literature and identified 64 cases with detailed clinical and genetic information. Orthostatic tremor associated with FXTAS is very rare. We found $85.2 \%$ patients reported tremor, $42.6 \%$ with intention tremor,36.1\% with kinetic tremor,32.8\% with rest tremor and $29.5 \%$ with posture tremor. $37.7 \%$ of patients who have tremor showed at least two types of tremor. There were 6 patients with isolated rest tremor. There was 2 patient with voice tremor and 6 with head tremor. We also found that 74.6\% FXTAS patients had family history of FMR1 gene associated diseases including Fragile X syndrome (FXS), FXTAS or fragile X-associated primary ovarian insufficiency (FXPOI).
\end{abstract}

Conclusions: Adding our data to the available literature suggests that orthostatic tremor could be a rare initial manifestation of FXTAS and the review will increasing our understanding the phenotype of tremor in FXTAS. Family history of FMR1 gene associated diseases might be an important clue to the diagnosis.

Keywords: Fragile X-associated tremor/ Ataxia syndrome, Orthostatic tremor, FMR1 gene,tremor, Ataxia

\footnotetext{
* Correspondence: zhaocuipingzsu@126.com

'Department of Neurology, Qilu Hospital, Shandong University, 44 Wenhua west Rd, Jinan 250012, China

Full list of author information is available at the end of the article
}

(C) The Author(s). 2020 Open Access This article is licensed under a Creative Commons Attribution 4.0 International License, which permits use, sharing, adaptation, distribution and reproduction in any medium or format, as long as you give appropriate credit to the original author(s) and the source, provide a link to the Creative Commons licence, and indicate if changes were made. The images or other third party material in this article are included in the article's Creative Commons licence, unless indicated otherwise in a credit line to the material. If material is not included in the article's Creative Commons licence and your intended use is not permitted by statutory regulation or exceeds the permitted use, you will need to obtain permission directly from the copyright holder. To view a copy of this licence, visit http://creativecommons.org/licenses/by/4.0/ The Creative Commons Public Domain Dedication waiver (http://creativecommons.org/publicdomain/zero/1.0/) applies to the data made available in this article, unless otherwise stated in a credit line to the data. 


\section{Background}

Fragile X-associated tremor/ataxia syndrome (FXTAS) is a late onset X-linked genetic neurodegenerative disorder caused by a "premutation (PM)" 55-200 CGG repeat expansion in the fragile $\mathrm{X}$ mental retardation 1 (FMR1) gene. The normal number of CGG of FMR1 is less than 45 CGG repeats in the 5' UTR region,gray zone contains 46-54 repeats (carriers with either movement disorders or memory complaints), premutation contains 55-200 repeats (causes FXTAS or FXPOI) and full mutation > 200(causes Fragile X syndrome). FXTAS mostly affects middle-aged and elderly men of 50-70 years old. The main motor features include tremor and cerebellar ataxia but there is high phenotypic variability with some carriers demonstrating parkinsonism, peripheral neuropathy, executive function deficits, dementia, and neuropsychiatric problems. The syndrome can mimic many common neurodegenerative disorders such as Parkinson's disease (PD), multiple system atrophy (MSA), Alzheimer disorders (AD), essential tremor (ET), and pure ataxia. Tremor is seen in $48-80 \%$ patients and variable in different studies and intention tremor is the most common pattern $[1,2]$. But it's very rare that FXTAS patients present with orthostatic tremor (OT). Here we report an old man with FXTAS from mainland of China who had OT as initial manifestation for 8 years. We also review more than 64 cases in the literature to find out the spectrum of tremor and other phenotype.

\section{Case presentation}

A 67-year-old right-handed farmer from the mainland of China was admitted to neurology department with slowly progressive tremor in limbs for 8 years. The tremor started from both lower limbs. It was only present while standing but absent when sitting,lying or walking. He had no problem in initiating the gait and no fall. The patient was diagnosed with essential tremor for long time and he was still functional in daily life without any medical therapy. Tremor became worse one and a half year ago and he felt unsteady. Tremor started in both arms 8 months ago which was remarkable when working with hands. Family history showed that his younger daughter stopped the menstruation at her 30s and the son of his youngest daughter had autism and attention deficit hyperactivity disorder (ADHD) (Fig. 1 C). Neurological examination revealed remarkable and visible tremor in both legs when standing still, intention tremor in both hands, mild postural tremor in both arms and rest tremor in left hand. He swayed on Romberg's test and had difficulty with tandem gait. He hadn't finger-nose and heel-shin incoordination,rigidity of limbs or nystagmus in eyes. The finger tapping was slow and clumsy bilaterally. His cognitive evaluations with Minimental State Examination (MMSE) and Montreal Cognitive Assessment (MoCA) were 28/30(education state: primary school) and 20/30 respectively. There was no muscle weakness, sensory disturbance or orthostatic
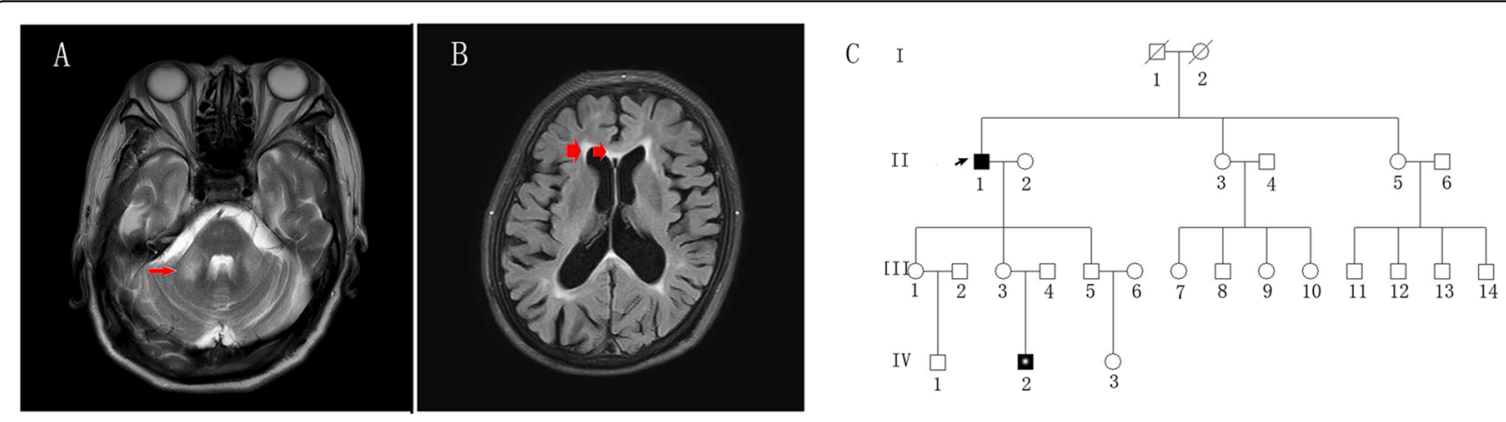

D

E
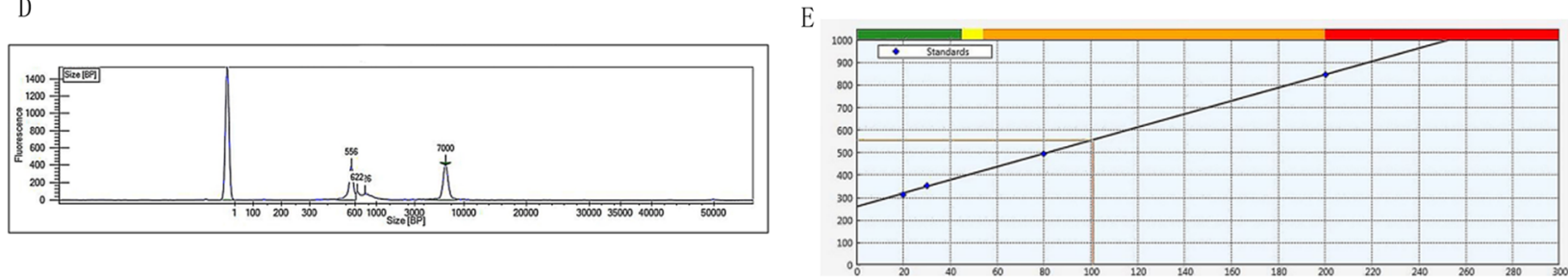

Fig. 1 a: Brain MRI of the patient showed symmetric T2 hyperintensity in bilateral medipeduncle (MCP sign,red arrow); b:showed abnormal FLAIR intensity in periventricular white matter area and corpus callosum (red arrow); c:Pedigree of the case. II1 was the patient with FXTAS. III 3 was his younger daughter who stopped the menstruation at her 30s.IV2 was the son of his youngest daughter and had autism and attention deficit hyperactivity disorder (ADHD). But III 3 and IV2 denied the gene test; $\mathbf{d}$ : Results of CGG repeat PCR of FMR1. The X-coordinate represents the fragment size and the Y-coordinate is the peak height. The fragment size of this patient is $556 \mathrm{bp}$, corresponding peak height is $396 \mathrm{bp}$, and other peaks are the reference materials for detection. e: Linear regression graph between CGG repeat numbers and main peak length. The intersection of yellow lines indicates the fragment size of this patient is $556 \mathrm{bp}$ and the number of CGG repeats is 101 
hypotension. Laboratory tests including blood cell counts, liver function, kidney function,thyroid function, ceruloplasmin and homocysteine were within the normal range. We found no abnormalities in the cerebrospinal fluid. Nerve conduction study values were within the normal range. The T2-weighted and fluid-attenuated inversion recovery (FLAIR) brain MRI indicated high intensity signals in the bilateral middle cerebellar peduncles (MCP),multiple sporadic high intensity signals in the cerebral white matter and atrophy of the cerebral cortex and cerebellum (Fig. 1a,b). FXTAS were considered and test for permutation of FMR1 gene was performed and showed positive with 101 CGG repeats (Fig. 1d,e). The patient met the the diagnosis criteria [3] with definite FXTAS. Because the heart beat was very low $(50-60 / \mathrm{min}) \beta$-receptor blocker was not used. Clonazepam $(0.5 \mathrm{mg}-1 \mathrm{mg} \mathrm{qn})$ and topiramate (primidone was not available) were administered and the tremor was relieved a little.

\section{Review on tremor in FXTAS}

We conducted a systematic review of the literature to identify primary clinical case report and case studies reporting individuals who were FXTAS diagnosed with clinical manifestation and gene testing. We searched for all English language papers published between January 2001 and June 2019 in PubMed with the term ("Fragile $\mathrm{X}$-associated Tremor Ataxia Syndrome" OR "FXTAS" and limited to case reports of patients who were (1) positive for premutation for the FMR1 gene and (2) described the clinical manifestations including tremor, ataxia,cognitive condition, parkinsonism and other symptoms in details especially about tremor. We analyzed and summarized the characters of these cases.

In total, we searched 552 articles with term Fragile Xassociated Tremor Ataxia Syndrome, we got 95 articles when limited to case report. We identified 33 articles reporting 64 patients fulfilling our inclusion criteria (Fig. 2). Reference 4 reported 19 patients with clinical information summarized in Tables but only 4 cases described in details so we included these 4 cases. The main findings of the review are summarized in Table 1 . We analyzed the clinical character and outlined in Table 2.

\section{Discussion and conclusion}

Here we report a rare case of FXTAS that OT was as initial manifestation for a long time. Studies have showed tremor in approximately $77 \%$ of men with FXTAS [36]. The tremor in FXTAS is typically bilateral intentional, postural or kinetic tremor in upper limbs, and although rest tremor may be seen in some patients it is often accompanied by intention tremor. Apartis et al. [37] reported that total of $86 \%$ of patients had tremor,action tremor resembling the tremor of ET in $35 \%$ of the patients, cerebellar intention tremor and postural tremor in $29 \%$, and unilateral upper

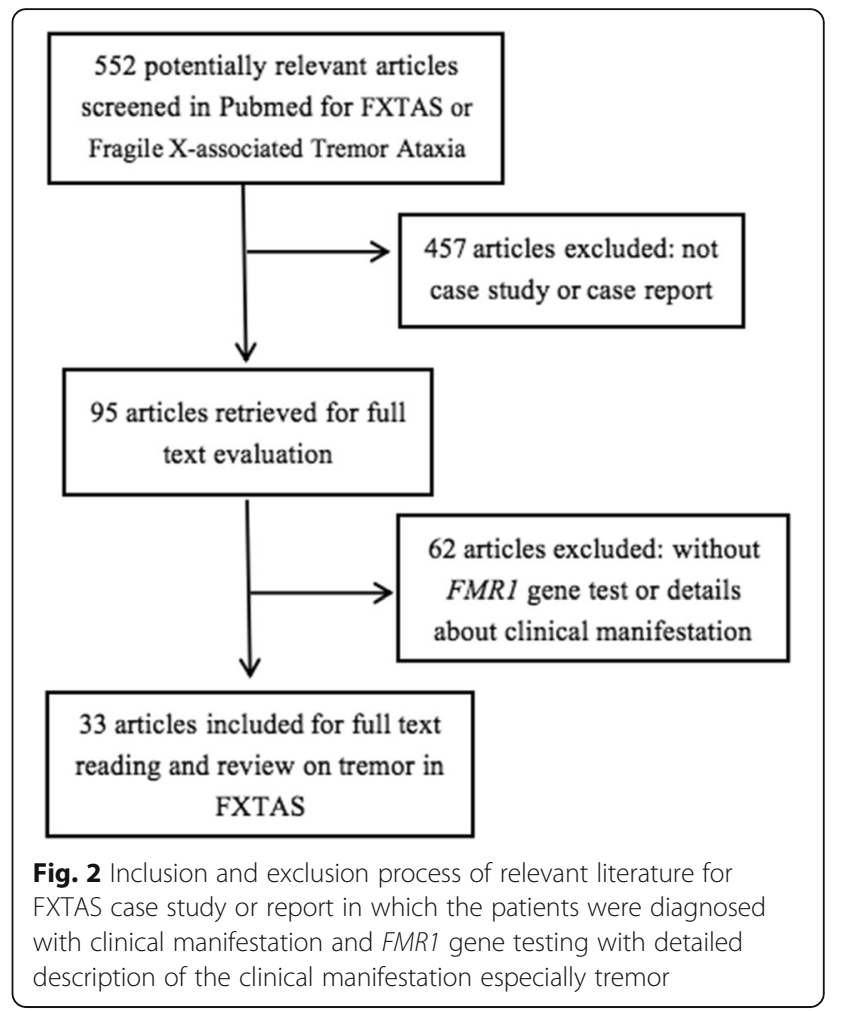

limb rest tremor in $12 \%$ in a study of 17 FXTAS patients using tremor recordings from a neuropack device.

The orthostatic tremor, also known as "shaky legs syndrome" was first coined in 1984 by Heilman and is an intriguing and rare condition, characterized by unsteadiness and tremor when standing that is relieved when sitting or walking which primarily affects the legs and trunk. As there are no published population-based epidemiological data, the prevalence and incidence of OT are unknown. In the Neurological Disorders of Central Spain (NEDICES) study [38], one group detected one OT patient in a cohort of approximately 4000 elderly subjects (data not published) [39]. Only recently there was a study reported othostatic tremor in their FXTAS cohort [35]. There is a broad spectrum in differential diagnosis of symptomatic OT, including non-tumoral aqueduct stenosis,chronic relapsing polyradiculoneuropathy, pontine lesions (such as Cavernoma, Tuberculoma), spinocerebellar ataxia type 2 , small cell lung cancer, stiff-person syndrome, Graves' disease and etc. [39] but rarely considering FXTAS. The tremor in both legs in our patient was orthostatic tremor according to the definition [40]. Idiopathic OT manifests with a highfrequency tremor $(13-18 \mathrm{~Hz})$. Fast (high frequency) OT may not be visible on routine examination, sometimes be palpable as a fine- amplitude rippling of leg muscles and might be heard noise using a stethoscope on the muscles of the legs but the patients rarely report tremor sensation as a presenting symptom. Slow $\mathrm{OT}(<13 \mathrm{~Hz})$ is 


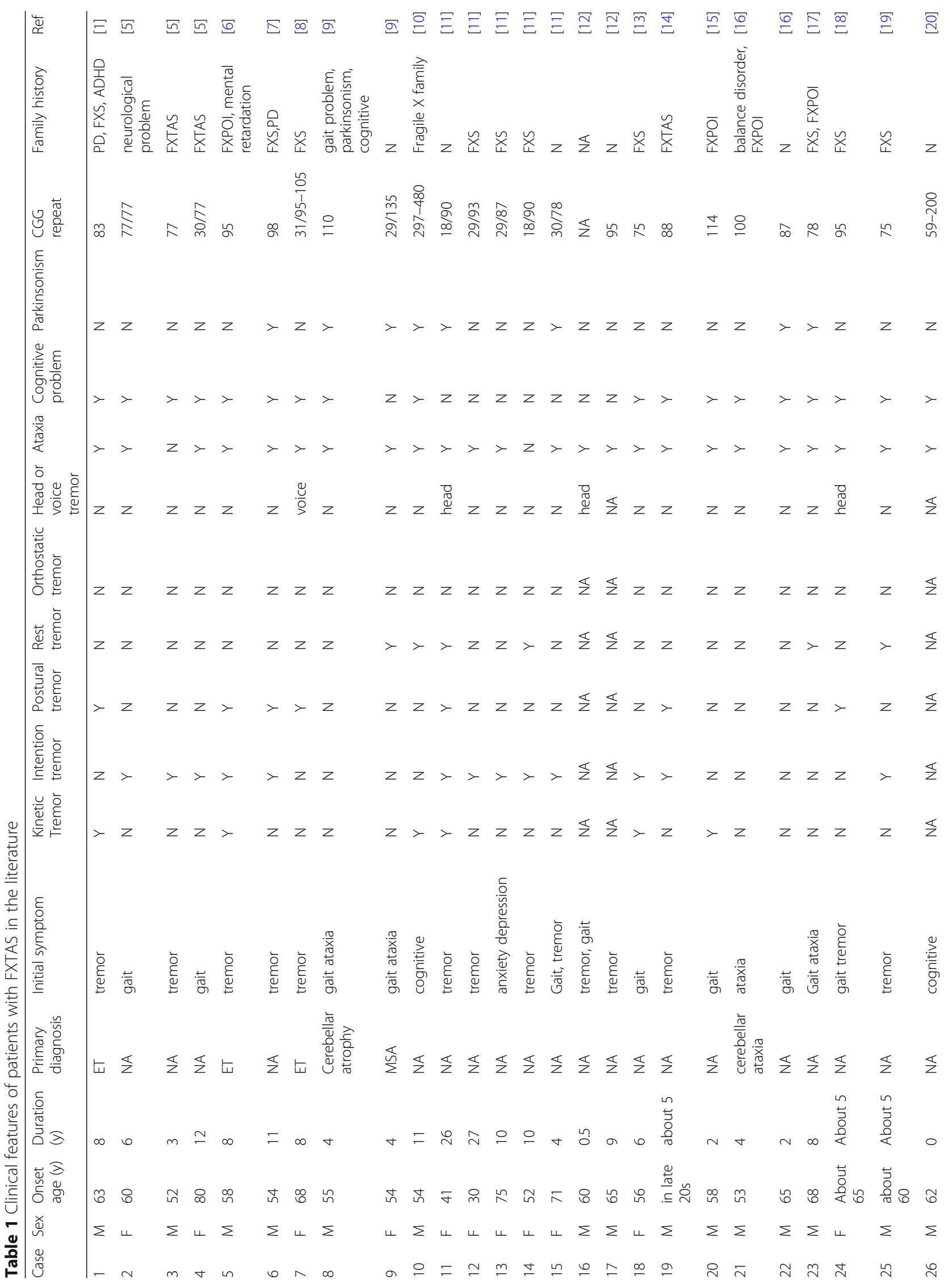




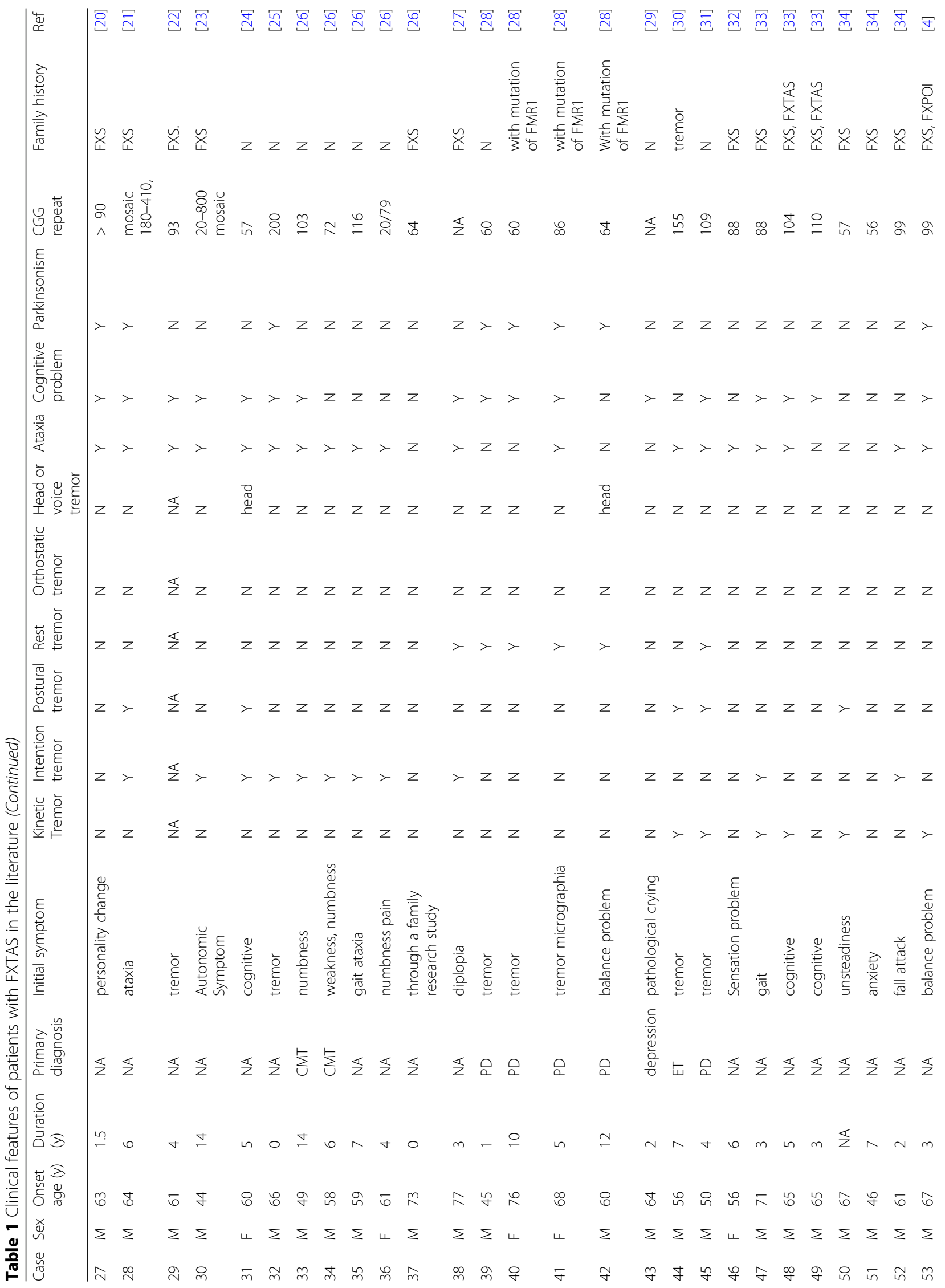




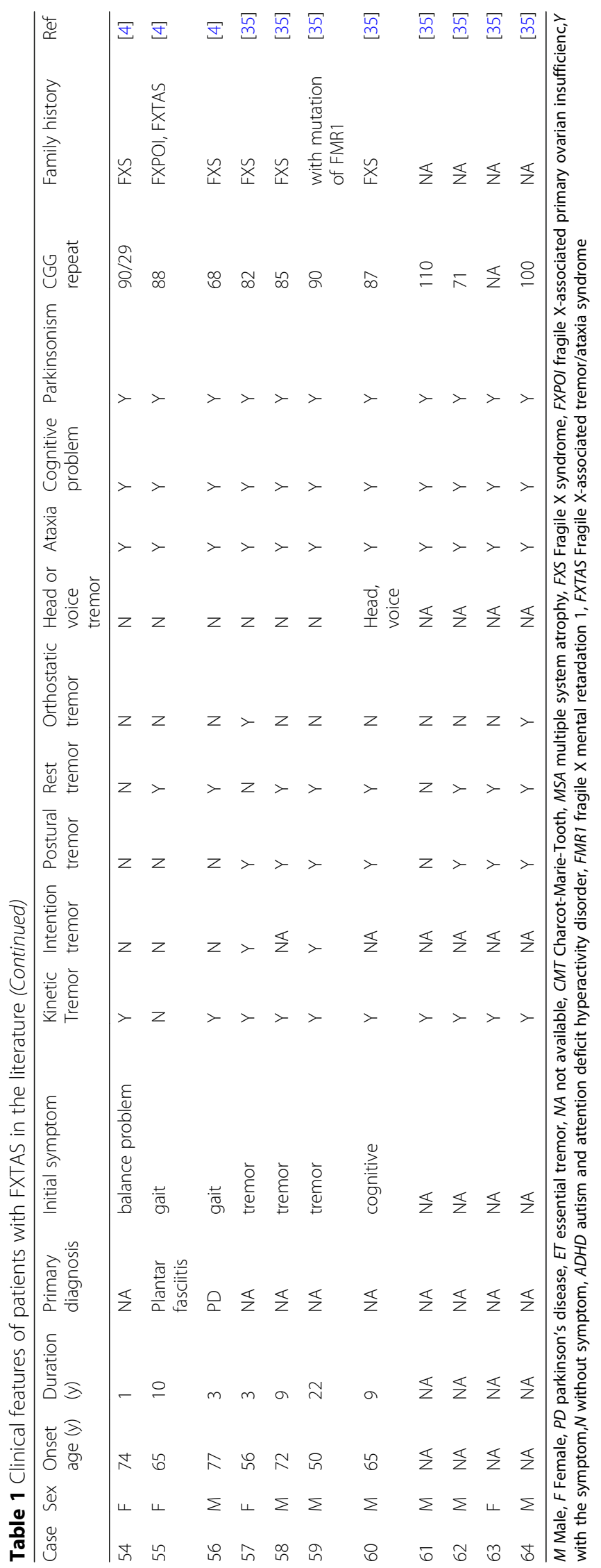


Table 2 Data summary of Clinical Characteristics of of reported FXTAS cases

\begin{tabular}{lllll}
\hline & Total $(\boldsymbol{n}=64)$ & Male $(\boldsymbol{n}=44)$ & Female $(\boldsymbol{n}=20)^{\boldsymbol{P}_{\text {-value }}}$ \\
\hline Onset age (years old) & $60.5(12.5)^{\mathrm{a}}$ & $59.0(10.5)$ & $61.5(14)$ & 0.376 \\
Duration before diagnosis (years) & $5.5(5.4)^{\mathrm{a}}$ & $4.8(5.6)$ & $5.8(5.2)$ & 0.026 \\
Positive family history(\%) & $44 / 59(74.6 \%)$ & $30 / 40(75.0)$ & $14 / 19(73.7 \%)$ & $19 / 20(95.0 \%)$ \\
Tremor(\%) & $52 / 61(85.2 \%)$ & $33 / 41(80.5 \%)$ & $11 / 20(55.5 \%)$ & 0.905 \\
Intention tremor(\%) & $26 / 61(42.6 \%)$ & $15 / 41(36.6 \%)$ & $5 / 20(25.0 \%)$ & 0.171 \\
Kinetic tremor(\%) & $22 / 61(36.1 \%)$ & $17 / 41(41.5 \%)$ & $7 / 20(35.0 \%)$ & 0.209 \\
Rest tremor(\%) & $20 / 61(32.8 \%)$ & $13 / 41(31.7 \%)$ & $4 / 20(20.0 \%)$ & 0.802 \\
Isolated rest tremor & $6 / 61(9.8 \%)$ & $2 / 41(4.9 \%)$ & $6 / 20(33.3 \%)$ & 0.063 \\
Posture tremor(\%) & $18 / 61(29.5 \%)$ & $12 / 41(29.3 \%)$ & $1 / 20(5.0 \%)$ & 0.952 \\
Orthostatic tremor & $2 / 61(3.3 \%)$ & $1 / 41(2.4 \%)$ & $1 / 20(5.0 \%)$ & 0.603 \\
voice tremor & $2 / 61(3.3 \%)$ & $1 / 41(2.4 \%)$ & $3 / 20(15 \%)$ & 0.603 \\
Head tremor & $6 / 61(9.8 \%)$ & $3 / 41(7.3 \%)$ & $6 / 20(30.0 \%)$ & 0.346 \\
More than two types of tremor(\%) & $23 / 61(37.7 \%)$ & $17 / 41(41.5 \%)$ & $17 / 20(85.0 \%)$ & 0.386 \\
Ataxia (\%) & $52 / 64(81.3 \%)$ & $35 / 44(79.6 \%)$ & $9 / 20(45.0 \%)$ & 0.604 \\
Parkinsonism(\%) & $28 / 64(43.8 \%)$ & $19 / 44(43.2 \%)$ & $34 / 44(77.3 \%)$ & 0.623 \\
Cognitive impairement(\%) & $46 / 64(71.9 \%)$ & & $12 / 20(60.0 \%)$ & 0.154 \\
\hline
\end{tabular}

a Median (interquartile range)

${ }^{b}$ Quantitative data is compared by Mann-Whitney $U$ test and categorical data is compared by Fisher exact test between male and female patients

usually sensed and reported by patients and visible on examination. In our patient it looked like low frequency though we didn't perform tremor anyalysis with tremorgram. There were other similar condition should be considered to differentiate from OT. Orthostatic myoclonus (OM) could be confused with OT, which also causes unsteadiness on standing and improves with walking or sitting but OM patients usually have non-rhythmic, synchronous and have difficulty in initiate gait. OM patients usually can't stand for long time because of jerk movement and orthostatic intolerance. Making the distinction between $\mathrm{OM}$ and OT requires electrophysiological studies. Unlike OT, the bursts are shorter in duration, non-rhythmic, and irregular. Our patient more likely had OT than OM because of other clinical aspects including the long history of the tremor with function, no fall and without problem of initiating gait.

In our review we found out that $85.2 \%$ patients reported tremor, $42.6 \%$ with intention tremor, $36.1 \%$ with kinetic tremor,32.8\% with rest tremor, $29.5 \%$ with posture tremor. $37.7 \%$ of patients with tremor showed at least two types of tremor. It was interesting that there were 6 patients with isolated rest tremor which was different from previous study $[36,37,41]$. There were 2 patients with voice tremor and 6 with head tremor which hasn't been addressed before. Orthostatic tremor in associated with FXTAS and our findings in the review will make us better understand the spectrum of tremors in FXTAS.

The premutation is also associated with fragile $\mathrm{X}$ associated primary ovarian insufficiency (FXPOI) in female and full-mutation carriers with over 200 repeats is associated with the Fragile X Syndrome (FXS), which is characterized by childhood-onset intellectual disability, seizures and autism. In western countries the FMR1 premutation occurs in $1 / 800$ males and 1/250 females, with FXTAS affecting $40-45 \%$ of male and $8-16 \%$ of female premutation carriers over the age of 50 [42]. It is estimated that there are many FXTAS patients in China because of the huge baseline population. From our review of the literature FXTAS was always misdiagnosed with PD, ET,MSA and other types of cerebellar ataxia. That is similar with the conclusion described in previous reports [43]. In mainland of China there were some studies which tried to find out FXTAS patients in many movement disorder cohorts. But there was negative result in screening FMR1 gene within premutaion range in $201 \mathrm{PD}, 36 \mathrm{ET}, 68$ sporadic spinocerebellar ataxia, 32 MSA patients and healthy control. But if we select subjects in the individuals with high risk we will find more FXTAS patients. In our review we found out that $74.6 \%(44 / 59)$ FXTAS patients had family history of FXS, FXTAS and/or FXPOI. If we do family investigation in FXS children and FXPOI females we will find more FXTAS patients or premutation carriers.

In summary, we demonstrated orthostatic tremor as a rare potential clinical feature of FXTAS. Our review about the tremor in FXTAS and presentaion with OT in our patient might expand the spectrum of tremor associated with FXTAS. Our study also highlight that family history of FXS, FXTAS and FXPOI can be an important clue to the diagnosis. 


\section{Abbreviations}

FXTAS: Fragile X-associated tremor/ataxia syndrome; FMR1: fragile X mental retardation 1 gene; PD: Parkinson's disease; MSA: Multiple system atrophy; AD: Alzheimer disorders; ET: Essential tremor; OT: Orthostatic tremor; ADHD: Attention deficit hyperactivity disorder; MMSE: Mini-mental State Examination; MoCA: Montreal Cognitive Assessment; MCP: Middle cerebellar peduncles; OM: Orthostatic myoclonus; FXS: Fragile X syndrome; FXPOI: FXTAS and/or fragile X-associated primary ovarian insufficiency

\section{Acknowledgements}

The authors are grateful to all subjects in our study.

\section{Authors' contributions}

CPZ initialed the study and wrote the manuscript. YML revised the manuscript. YHW, HYL, JYZ and BZ systemic reviewed the literature and made the Tables. YXY did data analyses. All authors approved the manuscript.

\section{Funding}

This study was supported by The National Key Research and Development Program of China (2016YFC0105901SDZ) in gene test for the patient,in analysis the data and for publication charge.

\section{Availability of data and materials}

All data generated or analysed during this study are included in this published article.

\section{Ethics approval and consent to participate}

No consent was necessary for this study.

\section{Consent for publication}

Written informed consent was obtained from the patients for publication of this case report. A copy of the written consent is available for review by the editor of this journal.

\section{Competing interests}

The authors declare that they have no competing interests.

\section{Author details}

${ }^{1}$ Department of Neurology, Qilu Hospital, Shandong University, 44 Wenhua west Rd, Jinan 250012, China. ²Department of Neurosurgery, Qilu Hospital, Shandong University, 44 Wenhua west Rd, Jinan 250012, China.

Received: 7 September 2019 Accepted: 13 April 2020

Published online: 20 April 2020

\section{References}

1. Ishii K, Hosaka A, Adachi K, Nanba E, Tamaoka A. A Japanese case of fragile- $X$ associated tremor/ataxia syndrome (FXTAS). Intern Med. 2010; 49(12):1205-8.

2. Hagerman RJ, Leehey M, Heinrichs W, Tassone F, Wilson R, Hills J, Grigsby J, Gage B, Hagerman PJ. Intention tremor, parkinsonism, and generalized brain atrophy in male carriers of fragile X. Neurology. 2001;57:127-30.

3. Hall DA, Birch RC, Anheim M, Jønch AE, Pintado E, O'Keefe J, Trollor JN, Stebbins GT, Hagerman RJ, Fahn S, Berry-Kravis E, Leehey MA. Emerging topics in FXTAS. J Neurodev Disord. 2014;6:31.

4. Fraint A, Vittal P, Szewka A, Bernard B, Berry-Kravis E, Hall DA. New observations in the fragile $X$-associated tremor/ataxia syndrome (FXTAS) phenotype. Front Genet. 2014;5:365.

5. Rodriguez-Revenga L, Pagonabarraga J, Gómez-Anson B, López-Mourelo O, Izquierdo S, Alvarez-Mora MI, Granell E, Madrigal I, Milà M. Carriage of one or two FMR1 Premutation alleles seems to have no effect on illness severity in a FXTAS female with an Autozygous FMR1 Premutation allele. Cerebellum. 2016;15(5):570-7.

6. Tamás G, Kovács N, Varga NÁ, Barsi P, Erőss L, Molnár MJ, Balás I. Deep brain stimulation or thalamotomy in fragile $\mathrm{X}$-associated tremor/ataxia syndrome? Case Rep Neurol Neurochir Pol. 2016;50(4):303-8.

7. Bourgeois JA, Farzin F, Brunberg JA, Tassone F, Hagerman P, Zhang L, Hessl $D$, Hagerman R. Dementia with mood symptoms in a fraile $X$ premutation carrier with the fragile $X$-associatedtremor/ ataxia syndrome: clinical intervention with donepezil and venlafaxine. J Neuropsychiatry Clin Neurosci. 2006;18(2):171-7.

8. Horvath J, Burkhard PR, Morris M, Bottani A, Moix I, Delavelle J. Expanding the phenotype of fragile $X$-associated tremor/ataxia syndrome: a new female case. Mov Disord. 2007;22(11):1677-8.

9. Biancalana V, Toft M, Le Ber I, Tison F, Scherrer E, Thibodeau S, Mandel JL, Brice A, Farrer MJ. Dürr A.FMR1 Premutations associated with fragile $X_{-}$ associated tremor/Ataxia syndrome in multiple system atrophy. Arch Neurol. 2005;62(6):962-6.

10. Loesch DZ, Sherwell S, Kinsella G, Tassone F, Taylor A, Amor D, Sung S, Evans A. Fragile $X$-associated tremor/ataxia phenotype in a male carrier of unmethylated full mutation in the FMR1 gene. Clin Genet. 2012;82(1):88-92.

11. Hagerman RJ, Leavitt BR, Farzin F, Jacquemont S, Greco CM, Brunberg JA, Tassone F, Hessl D, Harris SW, Zhang L, Jardini T, Gane LW, Ferranti J, Ruiz L, Leehey MA, Grigsby J, Hagerman PJ. Fragile-X-associated tremor/ataxia syndrome (FXTAS) in females with the FMR1 premutation. Am J Hum Genet. 2004;74(5):1051-6.

12. Kalus S, King J, Lui E, Gaillard F. Fragile X-associated tremor/ataxia syndrome: an under-recognised cause of tremor and ataxia. J Clin Neurosci. 2016;23: 162-4.

13. Karmon $Y$, Gadoth N. Fragile $X$ associated tremor/ ataxia syndrome (FXTAS) with dementia in a female harbouring FMR1 premutation. J Neurol Neurosurg Psychiatry. 2008;79(6):738-9.

14. Martínez-Cerdeño V, Lechpammer M, Lott A, Schneider A, Hagerman R. Fragile X-Associated Tremor/Ataxia Syndrome in a Man in His 30s. JAMA Neurol. 2015;72(9):1070-3.

15. Poston KL, McGovern RA, Goldman JS, Caccappolo E, Mazzoni P. Fragile Xassociated tremor/Ataxia syndrome (FXTAS) with myoclonus. Mov Disord. 2010;25(4):514-6.

16. Bajaj N, Soon D, Quinn N. Fragile X-associated tremor ataxia syndrome sine tremor. Mov Disord. 2011;26(10):1960-2.

17. Hagerman PJ, Hagerman RJ. Fragile X-associated tremor/ataxia syndrome-an older face of the fragile X gene. Nat Clin Pract Neurol. 2007;3(2):107-12.

18. O'Dwyer JP, Clabby C, Crown J, Barton DE, Hutchinson M. Fragile Xassociated tremor/ ataxia syndrome presenting in a woman after chemotherapy. Neurology. 2005;65(2):331-2

19. Michel AS, Claikens B. Fragile X-associated tremor/ ataxia syndrome. JBRBTR. 2012;95(3):156-7.

20. Connon P, Larner AJ. Fragile X-associated tremor/ataxia syndrome:Cognitive presentations. Br J Hosp Med (Lond). 2017;78(4):230-1.

21. Santa María L, Pugin A, Alliende MA, Aliaga S, Curotto B, Aravena T, Tang $H T$, Mendoza-MoralesG HR, Tassone F. FXTAS in an unmethylated mosaic male with fragile X syndrome from Chile. Clin Genet. 2014;86(4):378-82.

22. Mothersead PK, Conrad K, Hagerman RJ, Greco CM, Hessl D, Tassone F. Grand rounds: An atypical progressive dementia in a male carrier of the fragile X Premutation: an example of fragile X-associated tremor/Ataxia syndrome. Appl Neuropsychol. 2005;12(3):169-78.

23. Basuta K, Schneider A, Gane L, Polussa J, Woodruff B, Pretto D, Hagerman R, Tassone F. High functioning male with fragile $X$ syndrome and fragile $X$ associated tremor/Ataxia syndrome. Am J Med Genet A. 2015;167A(9):2154-61.

24. Ortigas MC, Bourgeois JA, Schneider A, Olichney J, Nguyen DV, Cogswell JB, Hall DA, Hagerman RJ. Improving fragile X-associated tremor/Ataxia syndrome symptoms with Memantine and venlafaxine. J Clin Psychopharmacol. 2010;30(5):642-4.

25. Saponara R, Greco S, Proto G, Trubia T, Domina E. Levetiracetam improves intention tremor in fragile $\mathrm{X}$-associated tremor/Ataxia syndrome. Clin Neuropharmacol. 2009;32(1):53-4.

26. Hagerman RJ, Coffey SM, Maselli R, Soontarapornchai K, Brunberg JA, Leehey MA, Zhang L, Gane LW, Fenton-Farrell G, Tassone F, Hagerman PJ. Neuropathy as a presenting feature in fragile $\mathrm{X}$-associated tremor/Ataxia syndrome. Am J Med Genet A. 2007;143A(19):2256-60.

27. Sulkowski GM, Kaufman LM. Oculomotor abnormalities in a patient with fragile X-associated tremor/ataxia syndrome. J AAPOS. 2008;12(2):195-6.

28. Hall DA, Howard K, Hagerman R, Leehey MA. Parkinsonism in FMR1 premutation carriers may be indistinguishable from Parkinson disease. Parkinsonism Relat Disord. 2009:15(2):156-9.

29. Van Ballaer K, Vandenbulcke M. Pathological crying associated with fragile X-associated tremor/Ataxia syndrome. J Neuropsychiatry Clin Neurosci. 2014; 26(4):E21-2.

30. Eye PG, Hawley JS. Pearls \& Oy-sters: fragile $X$ tremor/ataxia syndrome: a diagnostic dilemma. Neurology. 2015;84(7):e43-5. 
31. Oyama G, Umemura A, Shimo Y, Nishikawa N, Nakajima A, Jo T, Nakajima M, Ishii H, Yamada D, Takanashi M, Arai H, Nanba E, Hattori N. Posterior subthalamic area deep brain stimulation for fragile $X$-associated tremor/ Ataxia syndrome. Neuromodulation. 2014;17(8):721-3.

32. Chanson JB, Boehm N, Samama B, Echaniz-Laguna A, Anheim M. Small fiber neuropathy in a woman with fragile $X$-associated tremor/ataxia syndrome (FXTAS). J Neurol. 2015;262(1):226-7.

33. Winarni TI, Mundhofir FE, Ediati A, Belladona M, Nillesen WM, Yntema HG, Hamel BC, Faradz SM, Hagerman RJ. The fragile X-associated tremor ataxia syndrome (FXTAS) in Indonesia. Clin Genet. 2013;83(3):263-8.

34. Loesch DZ, Litewka L, Churchyard A, Gould E, Tassone F, Cook M. Tremor/ ataxia syndrome and fragile $X$ premutation: diagnostic caveats. I Clin Neurosci. 2007;14(3):245-8.

35. Fay-Karmon T, Hassin-Baer S. The spectrum of tremor among carriers of the FMR1 premutation with or without the fragile X-associated tremor/ataxia syndrome (FXTAS). Parkinsonism Relat Disord. Parkinsonism Relat Disord. 2019;65:32-8.

36. Juncos J, Lazarus J, Graves-Allen E, Shubeck L, Rusin M, Novak G, Hamilton D. New clinical findings in the fragile $X$-associated tremor ataxia syndrome (FXTAS). Neurogenetics. 2011;12:123-35.

37. Apartis E, Blancher A, Meissner W. FXTAS: new insights and the need for revised diagnostic criteria. Neurology. 2012;79:1898-907.

38. Benito-León J, Bermejo-Pareja F, Louis ED. Neurological Disorders in Central Spain Study Group. Incidence of essential tremor in three elderly populations of central Spain. Neurology. 2005;64:1721-5.

39. Benito-León J, Domingo-Santos Á. Orthostatic Tremor: An Update on a Rare Entity. Tremor Other Hyperkinet Mov (N Y). 2016;6:411-24.

40. Gerschlager W, Munchau A, Katzenschlager R. Natural history and syndromic associations of orthostatic tremor: a review of 41 patients. Mov Disord. 2004; 19:788-95.

41. Baba Y, Uitti R. Fragile X-associated tremor/ataxia syndrome and movements disorders. Curr Opin Neurol. 2005;18:393-8.

42. Hall DA, O'keefe JA. Fragile $X$-associated tremor ataxia syndrome: the expanding clinical picture, pathophysiology, epidemiology, and update on treatment. Tremor Other Hyperkinet Mov (NY). 2012;2.

43. Hall DA, Berry-Kravis E, Jacquemont S, Rice CD, Cogswell J, Zhang L, Hagerman RJ, Hagerman PJ, Leehey MA. Initial diagnoses given to persons with the fragile X associated tremor / ataxia syndrome (FXTAS). Neurology. 2005;65:299-301.

\section{Publisher's Note}

Springer Nature remains neutral with regard to jurisdictional claims in published maps and institutional affiliations.

Ready to submit your research? Choose BMC and benefit from:

- fast, convenient online submission

- thorough peer review by experienced researchers in your field

- rapid publication on acceptance

- support for research data, including large and complex data types

- gold Open Access which fosters wider collaboration and increased citations

- maximum visibility for your research: over $100 \mathrm{M}$ website views per year

At $\mathrm{BMC}$, research is always in progress.

Learn more biomedcentral.com/submissions 